\title{
Infertility diagnosis in jaguar (Panthera onca): case report
}

\section{Diagnóstico de infertilidade em onça pintada (Panthera onca): relato de caso}

\author{
Caroline Vieira de BARROS ${ }^{1}$; Natália Martins GALVÃO ${ }^{1}$; Silvia Laís CROCE ${ }^{1}$; Talyta Finoti Ferreira \\ TELES $^{1}$; Thalita Amorim de SOUZA ${ }^{1}$; Valéria Dias de ARAÚJO ${ }^{1}$; Vitor Hugo MORENO ${ }^{1}$; Victor Luiz \\ ROCHA $^{1}$; Guilherme Sellera GODOY ${ }^{1}$; Sandra Peres FERREIRA ${ }^{1}$; Tatiana Paula Alvarenga CARVALHO ${ }^{1}$; \\ Daniel de Souza Ramos ANGRIMANI ${ }^{2}$
}

\footnotetext{
${ }^{1}$ Centro Universitário Monte Serrat, Curso de Medicina Veterinária, Santos - SP, Brazil

${ }^{2}$ Universidade de São Paulo, Faculdade de Medicina Veterinária e Zootecnia, São Paulo - SP, Brazil
}

\begin{abstract}
This work reports one case of infertility in a male jaguar (Panthera onca) aged 21 years and weighing $125 \mathrm{~kg}$. Changes in sperm due to chronic stress, inadequate food handling and reproductive senescence are emphasized.

Keywords: Panthera onca. Infertility. Reproductive senescence. Wild animals reproduction.
\end{abstract}

\section{Resumo}

O presente trabalho relata um caso de infertilidade em uma onça-pintada (Panthera onca), macho, de 21 anos e 125 kg. São ressaltadas as alterações ocorridas nos espermatozoides, devido a estresse crônico, manejo alimentar inadequado e senescência reprodutiva.

Palavras-chave: Panthera onca. Infertilidade. Senescência reprodutiva. Reprodução animais silvestres.

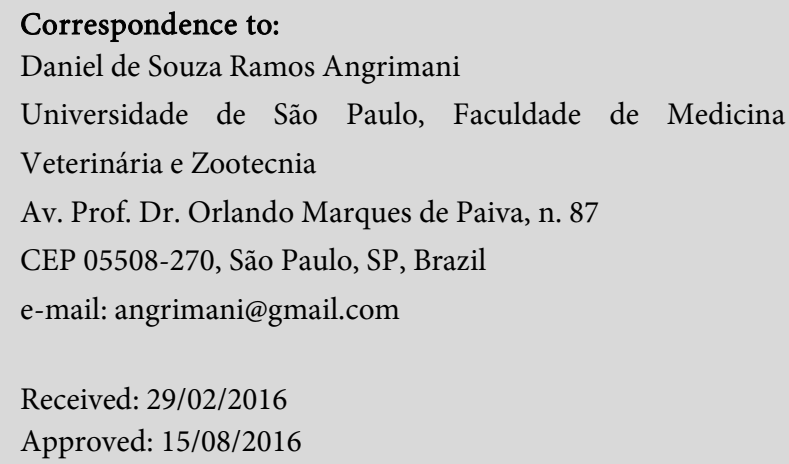

Jaguar (Panthera onca) is considered an endangered species in Brazil (MORATO et al., 2004). Among the factors that have threatened this population, loss of habitat mainly associated with agricultural expansion stands out (MORATO et al., 1999). Therefore, to reduce the loss of genetic diversity, targeted efforts to breeding animals in captivity should be applied (MICHELETTI et al., 2012). But the major problem is the chronic stress condition that animals develop in captivity due to limited space, management deficiencies, enclosure conditions (structure, hygiene and adaptations for the species), nutrition and clinical monitoring (MICHELETTI et al., 2012). Moreover, captive jaguars live an average of 20 years, in some cases, 27 years; conversely, in the natural environment, their lifetime is estimated at between 12 and 16 years (MIRANDA; JOHN, 2010). As a consequence of this senescence and captivity conditions, effects on spermatogenesis and ovulation can also occur, which may promote perinatal morbidity, mortality and even infertility (MORATO et al., 2004). Therefore, it is necessary to discuss and understand the reasons that trigger infertility in captive animals.

This study was carried out at the Ecological Park facilities of Voturuá, São Vicente (SP). A 21-year-old male Panthera onca weighing $125 \mathrm{~kg}$ was used. The animal was born in captivity and has no reproductive history. The enclosure was barred in a room with public view, with access to bath tank and night shelter. 
The animal showed injuries in the forelimb, anorexia and prostration. Chemical restraint was performed for curative purposes using ketamine $(10 \mathrm{mg} / \mathrm{kg})$ and xylazine $(1 \mathrm{mg} / \mathrm{kg})$, intramuscularly administered. Sedation was maintained with diazepam $(10 \mathrm{mg} / \mathrm{kg})$ during the procedure.

After chemical restraint, breeding soundness examination of the animal was carried out. Few spines were found on the penis. The right testicle had of $2 \mathrm{~cm}$ in width and $4 \mathrm{~cm}$ in height and the left testicle 2.54 $\mathrm{cm}$ and $3 \mathrm{~cm}$, respectively, values lower than previously described for jaguars (MORATO et al., 1999). Both had flaccid consistency. Blood was collected for the dosage of testosterone conducted with commercial kit (Testosterone Coat-ACount; Diagnostic Products Corporation, Los Angeles, CA, USA), where the value of $0.32 \mathrm{ng} / \mathrm{ml}$ was found, while the reference value was 1.0 to $6.0 \mathrm{ng} / \mathrm{mL}$ (MORATO et al., 2004). The seminal collection was carried out following the pattern of electrical stimulation procedure (PLATZ; SEAGER, 1978). The Torjet 65C device (Eletrovet, São Paulo, SP, Brazil) was used. The collected semen was analyzed in conventional microscope in which azoospermia was found. Due to the advanced age of the animal, his critical health condition (anorexia and prostration) and anesthetic complications during the curative procedure, the jaguar experienced cardiac arrest and death. The necropsy after the macroscopic examination revealed cardiac arrest as the cause of death. Moreover, scrotum, testes and epididymis were macroscopically evaluated. During examination, excess adipose tissue adjacent to the gonads was observed (Figure 1). Histopathological examination was performed with testis and epididymis after fixation in 10\% formalin, where diffuse and severe interstitial fibrosis associated with atrophy of the seminiferous tubules was detected. In the rare seminiferous tubules found, no sperm was observed.

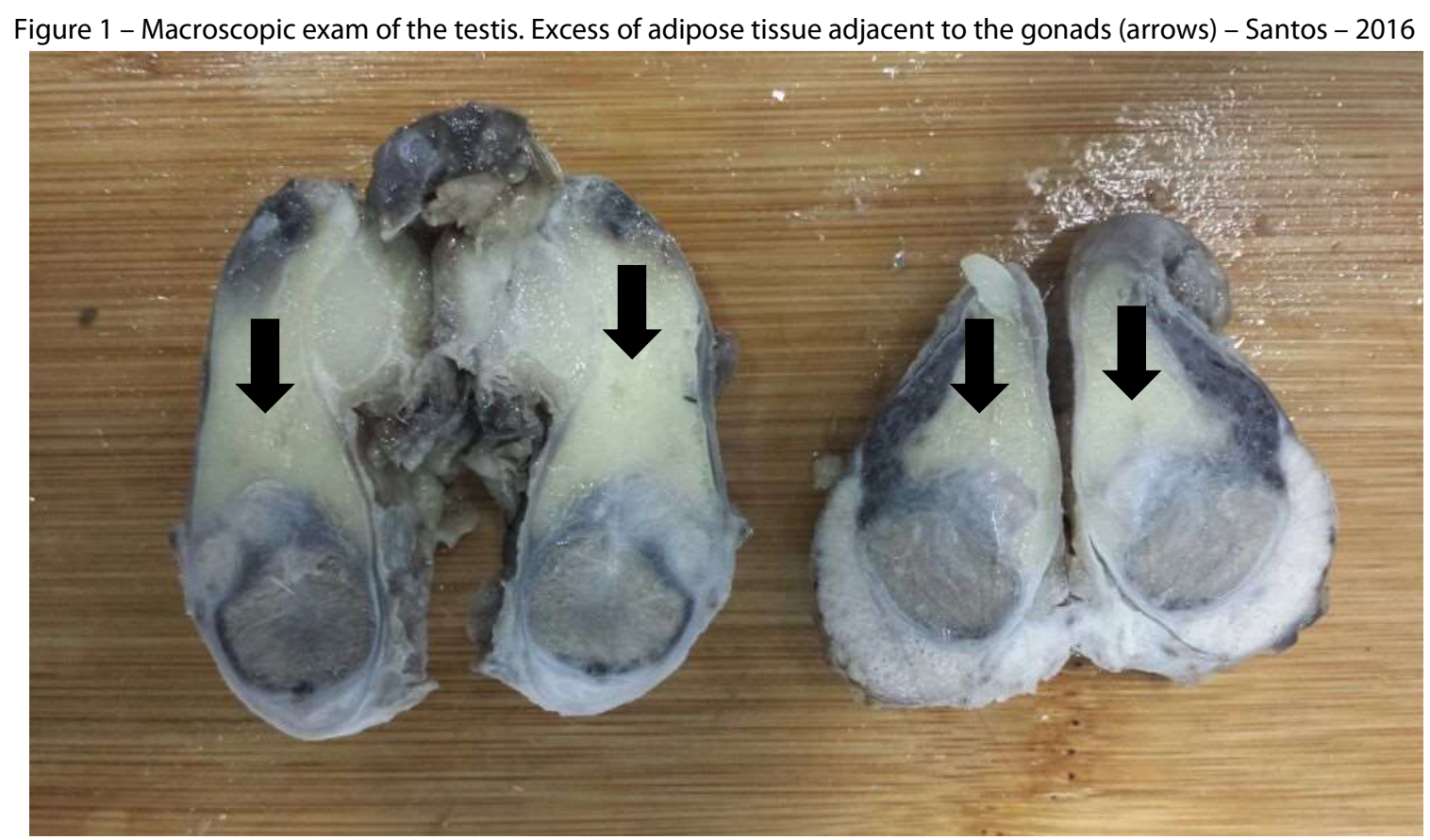

According to Hafez and Hafez (2004) and Morato et al. (1999), sperm changes may be due to congenital, nutritional, metabolic causes, chronic stress and by the aging process. In fact, aged animals have a decrease in testosterone production by the Leydig cells (CUNNINGHAM, 2008). In humans, for example, testosterone decreases gradually after 40 years (MORLEY, 2000). To our knowledge, these data have 
not been studied in jaguars; however, in this study, the animal had a lower testosterone rate and was 21 years old, whereas the lifetime of a wild jaguar is estimated at 12 to 16 years (MIRANDA; JOHN, 2010). Therefore, we presume that this age for Panthera onca may indicate the reproductive senescence, which can cause a lower testosterone production and poor sperm quality.

Moreover, Miranda and John (2010) estimate that the average weight of an adult Panthera onca is between 56 to $96 \mathrm{~kg}$, and in the Brazilian Pantanal, there is the presence of larger animals, reaching up to $100 \mathrm{~kg}$. The animal of this study was overweight (125

\section{References}

CUNNINGHAM, J. G. Tratado de fisiologia veterinária. Rio de Janeiro: Elsevier, 2008. 710 p.

HAFEZ, E. S. E.; HAFEZ, B. Reprodução animal. Barueri: Manole, 2004. 513 p.

MICHELETTI, T.; CUBAS, Z. S.; MORAES, W.; OLIVEIRA, M. J.; MOREIRA, N. Reprodução natural de felídeos selvagens em cativeiro: dificuldades e orientações. Revista Brasileira de Reprodução Animal, v. 36, n. 1, p. 39-43, 2012. Available from: <https:/goo.gl/HTxTJ1>. Viewed: 15 Feb. 2016.

MIRANDA, E. E; JOHN, L. Jaguar: o rei das Américas. São Paulo: Metalivros, 2010. 299 p.

MORATO, R. G.; GUIMARÃES, M. A. B. V.; FERREIRA, F.; VERRESCHI, I. T. N.; BARNABE, R. C. Reproductive characteristics of captive male jaguars (Panthera onca). Brazilian Journal of Veterinary Research and Animal $\mathrm{kg}$ ), contributing to the accumulation of adipose tissue adjacent to the testicle, leading to fibrosis and atrophy, thus hampering testosterone production by the Leydig cells (CUNNINGHAM, 2008). Thus, preventive examinations in order to detect pathological changes are required. Furthermore, it is possible to maximize the reproductive potential of captive animals using seminal biotechnologies (i.e. cryopreservation) during the reproductive age. In addition, measures such as environmental enrichment in the enclosure, mixed with a physical activity routine and proper nutrition are necessary to good quality of life of captive animals.

Science, v. 36, n. 5, p. 262-266, 1999. doi: 10.1590/S141395961999000500008.

MORATO, R. G.; BUENO, M. G.; MALMHEISTER, P.; VERRESCHI, I. T. N.; BARNABE, R. C. Changes in the fecal concentrations of cortisol and androgen metabolites in captive male jaguars (Panthera onca) in response to stress. Brazilian Journal of Medical and Biological Research, v. 37, n. 12, p. 1903-1907, 2004. doi: 10.1590/S0100-879X2004001200017.

MORLEY, J. E. Testosterone treatment in older men: effects on the prostate. Endocrine Practice, v. 6, n. 2, p. 218-221, 2000. doi: 10.4158/EP.6.2.218.

PLATZ, C. C.; SEAGER, W. J. Semen collection by electroejaculation in the domestic cat. Journal of the American Veterinary Medical Association, v. 173 n. 10, p. 1353-1355, 1978. 